\title{
Tax Policy and Corporate Investment
}

\author{
LAWRENCE H. SUMMERS
}

\section{INTRODUCTION}

The proposition that the level of business fixed investment in the United States should be increased commands almost universal support. Increasing the rate of investment is widely seen as a panacea for a variety of economic problems including inflation, declining productivity, and the fall of the dollar. While there is agreement as to the inadequacy of business fixed investment, there is little agreement as to the causes of the shortfall. For example, in a recent proceedings volume of the American Economic Review, Alan Blinder concludes with Robert Hall that "The principal source of inadequate capital formation has been our fallure to do anything about recessions, not our active use of anti-investment stimulative policies," while Martin Feldstein (1980) argues that the interaction of inflation and taxation accounts for much of the decline in corporate capital accumulation that has taken place over the last decade.

This paper presents an overview of the issues connected with the relationship between tax policy and corporate investment. In the first section of the paper, post-war trends in capital formation and corporate sector profitability are examined. While the share of gross investment in GNP has remained almost constant, the rate of net productive investment expressed as either a fraction of GNP or of the capital stock has fallen sharply during the 1970s. This decline has been associated with a substantial fall in the market price of corporate capital, and in the after-tax rate of return to investors in the corporate sector. The reduction in after-tax returns to corporate investors, while partially telated to a fall in the pre-tax rate of return on capital, is in large part due to the interactions of inflation and our non-indexed tax system.

The second section presents a cautious view of the social gains from increased corporate investment. Even a large increase in net

Lawrenee H. Summers is Assistant Professor of Economics, Massachusetts Institute of Technology and Research Associate, National Bureau of Econoric Research, Cambridge, Mass. 
business investment would not be sufficient to offset more than a small part of the productivity slowdown. Given a fixed path of monetary policy, tax reductions to spur investment are likely to increase rather than reduce the rate of inflation. The real payoff from increased investment, it is argued, comes from the very favorable terms of trade between consumption today and tomorrow. Foregoing a dollar today leads to an increase in potential consumption of two dollars only seven years hence. At these rates, most persons would find more investment attractive.

Traditional econometric studies of the relationship between tax policies and investment are reviewed in the third section. It is argued that the type of investment equations embodied in most large scale econometric models do not offer meaningful guidance as to the effects of tax policy on investment. Since output is traditionally held constant, the capacity effects of increased investment cannot be captured in these formulations. As fundamental, the usual approach yields results which are very inconsistent with the assumption that expectations are rational. As an example of the misleading nature of standard econometric investment equations, the role of general expansionary policy as a device for spurring investment is considered. It is argued that as long as one accepts the view that there is no long rm Phillips curve tradeoff, it is not possible for the level of general stimulus to have any effect on the long-run growth of the capital stock. The accelerator does not offer a useful route to increasing corporate investment.

An alternative methodology for viewing corporate investment incentives is presented in the fourth section. It is shown that an asset price approach to evaluating investment incentives avoids the difficulties inherent in traditional investment equations and avoids the "Lucas critique" of being unstable across changes in policy regimes. The effects of various tax policies on investment are analyzed using this approach. It is argued that through judicious policy choices substantial stimulus to investment can be achieved without any large revenue cost to the government.

The fifth section examines the general equilibrium effects of a change in business taxation. It is argued that business tax incentives can only spur investment if the supply of savings flowing to the corporate sector is increased. This can occur in one of two ways. An increase in the after-tax tate of return may raise the savings rate. Alternatively, it may lead to an increase in the share of wealth allocated to the corporate sector. Each of these mechanisms is 
examined briefly. The paper concludes by discussing the appropriate macroeconomic policy mix to accompany business tax reductions.

\section{INVESTMENT AND THE PERFORMANCE OF THE NON.FINANCIAL CORPORATE SECTOR}

This section examines trends in the rate of non-financial corporate investment, and profitability during the post-war period. The focus here is on corporate capital formation because its alleged deficiencies have received the most attention and it is most plausibly influenced by tax policies. It is important to recognize, however, that corporate investment makes up only about 60 percent of the total. About 25 percent of investment is residential and the remainder is done by non-corporate business. The trends illustrated here hold for total business investment as well. There have been rather divergent movements in the rate of residential investment and the valuation of housing capital. These are examined in the paper's final section.

\section{TRENDS IN THE RATE OF CORPORATE INVESTMENT}

Various measures of the rate of non-financial corporate capital investment are displayed in Table 1. The type of measure most usually relied on, a comparison of gross investment with gross output, is shown in Table 1. It has been surprisingly constant throughout the 1951.79 period, and has been close to its long-term average during the last decade. However, focusing on gross investment may be very misleading. The key variable for economic performance is the rate of growth of the capital stock. This depends on net investment rather than gross investment. The rate of net investment as a fraction of gross corporate product has declined quite sharply in the last decade as shown in column $2 .{ }^{1}$ While it averaged 0.036 over the entire 1951-79 period, it averaged only 0.024 during the 1975-79 recovery period. This corresponds to a 33 percent reduction in the rate of net capital formation.

There is a second important issue involved in assessing investment performance during the 1970 s. Regulatory requirements imposed in order to protect the environment and workers' safety have forced

\footnotetext{
${ }^{1}$ These estimates are based on the assumptions of straight line depreciation and service lines of .85 Bulletin $F$. There is a strong argument to be fnade that both these assumptions are conservative and so these figures understate depreciation and overstate net investment.
} 


\section{TABLE 1}

Alternative Measures of the Rate of Non-Financial

Corporate Investment

\begin{tabular}{|c|c|c|c|c|}
\hline & Gross I & Net I & $\begin{array}{l}\text { Pollution Ad- } \\
\text { justed Net I }\end{array}$ & $\begin{array}{l}\text { Pollution Ad- } \\
\text { justed Net I }\end{array}$ \\
\hline Year & $\mathrm{Y}$ & $Y$ & $\mathrm{Y}$ & $\mathrm{K}$ \\
\hline 1951 & 0.138 & 0.045 & 0.045 & 0.043 \\
\hline 1952 & 0.134 & 0.038 & 0.038 & 0.036 \\
\hline 1953 & 0.138 & 0.042 & 0.042 & 0.041 \\
\hline 1954 & 0.137 & 0.034 & 0.034 & 0.031 \\
\hline 1955 & 0.136 & 0.039 & 0.039 & 0.038 \\
\hline 1956 & 0.146 & 0.047 & 0.047 & 0.045 \\
\hline 1957 & 0.146 & 0.044 & 0.044 & 0.041 \\
\hline 1958 & 0.131 & 0.021 & 0.021 & 0.018 \\
\hline 1959 & 0.124 & 0.022 & 0.022 & 0.021 \\
\hline 1960 & 0.131 & 0.030 & 0.030 & 0.028 \\
\hline 1961 & 0.128 & 0.025 & 0.025 & 0.024 \\
\hline 1962 & 0.129 & 0.033 & 0.033 & 0.032 \\
\hline 1963 & 0.125 & 0.031 & 0.031 & 0.032 \\
\hline 1964 & 0.130 & 0.039 & 0.039 & 0.041 \\
\hline 1965 & 0.141 & 0.053 & 0.053 & 0.057 \\
\hline 1966 & 0.146 & 0.059 & 0.059 & 0.064 \\
\hline 1967 & 0.139 & 0.049 & 0.047 & 0.050 \\
\hline 1968 & 0.136 & 0.047 & 0.045 & 0.048 \\
\hline 1969 & 0.138 & 0.048 & 0.046 & 0.048 \\
\hline 1970 & 0.133 & 0.037 & 0.034 & 0.034 \\
\hline 1971 & 0.129 & 0.032 & 0.027 & 0.027 \\
\hline 1972 & 0.128 & 0.035 & 0.029 & 0.031 \\
\hline 1973 & 0.135 & 0.043 & 0.036 & 0.039 \\
\hline 1974 & 0.140 & 0.040 & 0.033 & 0.033 \\
\hline 1975 & 0.123 & 0.016 & 0.009 & 0.008 \\
\hline 1976 & 0.120 & 0.017 & 0.010 & 0.010 \\
\hline 1977 & 0.127 & 0.027 & 0.021 & 0.021 \\
\hline 1978 & 0.124 & 0.028 & 0.022 & 0.024 \\
\hline 1979 & 0.127 & 0.032 & 0.025 & 0.027 \\
\hline
\end{tabular}


TABLE 1 (continued)

$\begin{array}{lllll}51.54 & 0.137 & 0.040 & 0.040 & 0.038 \\ 55.59 & 0.137 & 0.035 & 0.035 & 0.032 \\ 60-64 & 0.129 & 0.037 & 0.031 & 0.031 \\ 65-69 & 0.140 & 0.051 & 0.050 & 0.053 \\ 70-74 & 0.133 & 0.037 & 0.032 & 0.032 \\ 75-79 & 0.124 & 0.024 & 0.017 & 0.018 \\ \text { T 51-79 } & 0.133 & 0.036 & 0.034 & 0.034\end{array}$

Source: as described in text.

firms to engage in capital investment. ${ }^{2}$ This investment does not add to the productive (in terms of measured output) capital stock.

Hence, it should not be included in assessing changes in capacity expanding investment. Data is available from the Department of Commerce on the share of investment outlays devoted to pollution control but not for occupational safety. These outlays have risen sharply during the 1970s. In columns 3 and 4 , net productive investment is expressed as a fraction of gross corporate output, and of the corporate capital stock. They show very pronounced declines during the $1970 \mathrm{~s}$. The rate of growth of the non-financial corporate sector's capital stock in column 4 averaged only 2.5 percent during the 1970 s compared with 3.9 percent during the $1951-1969$ period. A similar pattern is exhibited by the data in column 3. The evidence suggests that the rate of corporate capital formation has declined significantly during the 1970 s. This conclusion would be strengthened if account were taken of occupational safety investment expenditures, and the more rapid depreciation of the capital stock, which has occurred due to rising energy prices, ${ }^{3}$

\footnotetext{
${ }^{2}$ It should be emphasized that pollution control expenditures are productive, in that they provide for clean air and water. These benefits are real even though they do not show up in measured GNP. However, there is no apparent reason why a social decision to increase environmental quality should lead to a decline in the rate of "normal" investment. Hence, the appropriate standard of comparison is investment net of pollution control expenditures.

"The impact of higher energy prices has been to reduce slibstantially the value of existing capital which is energy inefficient. If this extra component were added to depreciation, estimated net investment would decline even further. If one assumes that the energy shock rendered even 5 percent of the capital stock obsolete, the average net investment rate over the last seven years declines by .007 , or over onefourth of its average level.
} 
TABLE 2

Cyclically Adjusted Rates of Investment

Pollution Ad- Pollution Ad-

\begin{tabular}{ccccc} 
& Gross I & Net I & justed Net I & justed Net I \\
\cline { 2 - 3 } Year & Y & $\frac{Y}{Y}$ & Y & K \\
\hline 1956 & 0.143 & 0.042 & 0.042 & 0.039 \\
1957 & 0.144 & 0.041 & 0.041 & 0.037 \\
1958 & 0.136 & 0.038 & 0.038 & 0.039 \\
1959 & 0.132 & 0.032 & 0.031 & 0.030 \\
1960 & 0.135 & 0.037 & 0.037 & 0.036 \\
1961 & 0.134 & 0.041 & 0.041 & 0.041 \\
1962 & 0.135 & 0.041 & 0.040 & 0.040 \\
1963 & 0.127 & 0.034 & 0.034 & 0.035 \\
1964 & 0.130 & 0.037 & 0.037 & 0.038 \\
1965 & 0.138 & 0.046 & 0.046 & 0.049 \\
1966 & 0.140 & 0.047 & 0.047 & 0.050 \\
1967 & 0.131 & 0.035 & 0.033 & 0.034 \\
1968 & 0.127 & 0.029 & 0.029 & 0.030 \\
1969 & 0.129 & 0.031 & 0.029 & 0.029 \\
1970 & 0.127 & 0.029 & 0.026 & 0.026 \\
1971 & 0.128 & 0.032 & 0.027 & 0.027 \\
1972 & 0.128 & 0.033 & 0.027 & 0.028 \\
1973 & 0.131 & 0.036 & 0.028 & 0.030 \\
1974 & 0.136 & 0.035 & 0.028 & 0.027 \\
1975 & 0.128 & 0.033 & 0.027 & 0.030 \\
1976 & 0.130 & 0.032 & 0.025 & 0.027 \\
1977 & 0.132 & 0.034 & 0.028 & 0.029 \\
1978 & 0.125 & 0.027 & 0.021 & 0.022 \\
1979 & 0.125 & 0.028 & 0.021 & 0.022 \\
& & & &
\end{tabular}

$\begin{array}{lllll}56-59 & 0.139 & 0.038 & 0.038 & 0.036 \\ 60-64 & 0.132 & 0.038 & 0.038 & 0.038 \\ 65-69 & 0.133 & 0.038 & 0.037 & 0.038 \\ 70-74 & 0.130 & 0.033 & 0.027 & 0.028 \\ 75-79 & 0.128 & 0.031 & 0.024 & 0.026 \\ \text { T 56-79 } & 0.132 & 0.036 & 0.033 & 0.033\end{array}$

Source: as described in text. 
Even casual inspection of Table 1 shows that the state of the business cycle has a large impact on the rate of corporate investment. The rate of investment by any of the measures peaks in the boom years of the mid-60s, and reaches its low in 1975. In assessing the long-term trends which should guide tax policy, it is useful to abstract from cyclical factors. This is done by calculating the cyclically adjusted rates of investment shown in Table 2 . The cyclical adjustments are based on regression equations of the form:

$$
\mathrm{R}_{\mathrm{t}}=\alpha_{0}+\alpha_{1} \mathrm{RUMM}_{\mathrm{t}}+\alpha_{2} \mathrm{RUMM}_{\mathrm{t}-1}+\mathrm{u}_{\mathrm{t}}
$$

where $R_{t}$ is the rate of investment, and $R U M M_{t}$ is the married-male unemployment rate which is used as a cyclical indicator, ${ }^{4}$ The cyclically adjusted investment rate $\hat{R}_{t}$ is calculated as:

$$
\hat{R}_{\mathrm{t}}=\mathrm{R}_{\mathrm{t}}-\alpha_{\mathrm{l}}\left(\mathrm{RUMM}_{\mathrm{t}}-\overline{\mathrm{RUMM}}\right)-\alpha_{2}\left(\mathrm{RUMM}_{\mathrm{t}-\mathrm{l}}-\overline{\mathrm{RUMM}}\right)
$$

.It corresponds to the rate of investment which would have taken place if the unemployment rate had been at its mean level.

The results show that the decline in net productive investment in the 1970 s is not a cyclical artifact. The share of corporate product (column 3) going to this source on a cyclically adjusted basis has declined from 3.8 percent during the 1956-1959 period to 2.5 percent during the 1970s. Thus, the decline in investment is almost as great on a cyclically adjusted basis as on a cyclically unadjusted basis. This conclusion also holds for the other measures of the investment rate. The conclusion that the 1970 s have witnessed a large reduction in investment, inexplicable on the basis of cyclical factors, appears almost inescapable. Below we examine some possible underlying causes including the rate of profit and the extent of capital taxation.

\section{TRENDS IN CORPORATE PROFITABILITY}

The data in Tables 1 and 2 illustrate the declines in investment. Table 3 shows how various indicators of corporate profitability have evolved over the last 25 years. The first column shows the pretax rate of profit of the corporate sector. While the rate of profit has declined somewhat in the $1970 \mathrm{~s}$, it appears to have been fairly constant at about 11 percent over the entire period. The second column shows the total tax rate on corporate capital arising from

"Similar results were obtained using other indicators of the cyclical condtions such as the unemployment rate of all men 25 and over, the GNP gap, and the rate of capacity utilization. 
TABLE 3

Corporate Sector Profitability

\begin{tabular}{|c|c|c|c|c|}
\hline Year & $\begin{array}{l}\text { Total Rate } \\
\text { of Return }\end{array}$ & $\begin{array}{l}{ }^{\text {b Total }} \\
\text { Effective } \\
\text { Tax Rate }\end{array}$ & $\begin{array}{l}{ }^{b} \text { Real Net } \\
\text { Rate of } \\
\text { Return }\end{array}$ & $\begin{array}{l}\text { 'Ratio of } \\
\text { Market Value to } \\
\text { Replacement Cost } \\
\text { of Net Assets }\end{array}$ \\
\hline 1955 & 13.2 & 66.5 & 4.4 & 0.92 \\
\hline 1956 & 11.4 & 72.4 & 3.2 & 0.92 \\
\hline 1957 & 10.5 & 71.7 & 3.0 & 0.85 \\
\hline 1958 & 9.0 & 70.7 & 2.6 & 0.87 \\
\hline 1959 & 11.2 & 67.3 & 3.6 & 1.04 \\
\hline 1960 & 10.4 & 66.5 & 3.5 & 1.02 \\
\hline 1961 & 10.3 & 66.4 & 3.5 & 1.14 \\
\hline 1962 & 11.7 & 61.5 & 4.5 & 1.09 \\
\hline 1963 & 12.4 & 60.6 & 4.9 & 1.20 \\
\hline 1964 & 13.4 & 56.2 & 5.9 & 1.29 \\
\hline 1965 & 14.5 & 55.1 & 6.5 & 1.35 \\
\hline 1966 & 14.5 & 56.0 & 6.4 & 1.20 \\
\hline 1967 & 13.0 & 56.4 & 5.7 & 1.21 \\
\hline 1968 & 13.0 & 62.6 & 4.9 & 1.25 \\
\hline 1969 & 11.7 & 67.3 & 3.8 & 1.12 \\
\hline 1970 & 9.6 & 70.5 & 2.8 & 0.91 \\
\hline 1971 & 10.0 & 67.7 & 3.2 & 1.00 \\
\hline 1972 & 10.8 & 62.5 & 4.1 & 1.07 \\
\hline 1973 & 10.5 & 70.1 & 3.1 & 1.01 \\
\hline 1974 & 8.2 & 90.1 & 0.8 & 0.75 \\
\hline 1975 & 8.6 & 72.4 & 2.4 & 0.71 \\
\hline 1976 & 9.5 & 68.1 & 3.0 & 0.80 \\
\hline 1977 & 9.7 & 68.3 & 3.1 & 0.73 \\
\hline 1978 & 9.7 & 72.2 & 2.7 & 0.68 \\
\hline 1979 & 9.1 & 74.5 & 2.3 & 0.65 \\
\hline
\end{tabular}

Sources:

aFeldstein and Poterba, "State and Local Taxes and the Rate of Return on Non-

Financial Corporate Capital," NBER Working Paper \#508R, p. 10.

blbid., p. 23

Economic Report of the President, 1980, Table B-85. 
the combination of federal and state taxes at both the corporate and individual levels. A fuller discussion of the calculation of these effective tax rates is contained in Feldstein and Summers (1979) and Feldstein and Poterba (1980). These dara clearly show a very pronounced increase in the taxation of corporate capital during the 1970s. The tax rate has risen from 55.1 percent in 1965 to 74.5 percent in 1979 .

This increase in taxes has largely been the result of inflation. Inflation increases the taxation of corporate capital in three ways. The two most important are historical depreciation, which added over $\$ 25$ billion to corporate tax liabilities in 1979 , and the taxation of nominal inventory profits which raised corporate tax liabilities by over $\$ 30$ bilion in 1979. In addition, the taxation of nominal capital gains is estimated to have imposed a tax burden of over $\$ 10$ billion. It is frequently argued that these effects are offset by the fact that corporations can deduct nominal interest payments for tax purposes. This gain to corporations, however, is itself almost completely offset by the increase in individual taxes on nominal interest. Feldstein and Summers (1979) show that in assessing the fotal tax burden on corporate capital, the taxation of nominal interest nets out and can be neglected.

The after-tax rate of return on corporate capital is displayed in the thitd column. In the late $1970 \mathrm{~s}$ it fell to only about one-half of its level during the late 1960 s. From columns 1 and 2 it can be seen that over half of this fall can be attributed to increased taxes rather than to a decline in the pre-tax rate of return. This suggests that it may be taxation more than any decline in the return to capital which has accounted for the 1970s investment slowdown.

The values of Tobin's a ratio of the market value of the capital stock to its replacement cost are shown in columa 4. The large decline in the value of a during the 1970 s of course stands out. It is noteworthy that the 50 percent fall in $\mathrm{g}$ from the late $1960 \mathrm{~s}$ almost exactly parallels the fall in the net return to corporate capital shown in Table 3 . It appears that a significant portion of the fall in the total market valuation of corporate capital can be attributed to the extra tax burdens imposed by inflation. If one accepts a "q" theory of investment of the type discussed in the fourth section, this provides further support for the hypothesis that increased taxation

\footnotetext{
'This extra tax burden is in some sense voluntary sinee firms could avoid it by switching to LIFO inventory accounting. This does not make it less real. Firms presumably stay with FIFO because, rationally or irrationally, they perceive some intramarginal economic gain from doing so. Nonetheless inflation does penalize them by raising their tax burdens.
} 
has been an important cause of the decline in investment which has taken place during the 1970 s. Before examining the data bearing on this question, we turn in the next section to an analysis of the potential gains from increasing the rate of investment.

\section{THE GAINS FROM INCREASED INVESTMENT}

This section examines the potential social gains from tax policies designed to increase corporate investment. The arguments which have received the most popular attention, those linking investment to productivity, inflation and unemployment, are examined first. It is shown that none of these considerations provide a strong case for investment tax incentives. A case for teducing the tax burden on corporate capital is then developed in terms of micro- and macrointertemporal economic efficiency.

\section{INVESTMENT, PRODUCTIVTY AND GROWTH}

The poor performance of productivity in recent years has often been attributed to the low rate of growth of the capital stock. It is argued that increasing the rate of investment could have a large effect on the rate of growth over the next decade. This prospect seems unlikely. Prominent studies of the productivity slowdown, Denison (1979), Norsworthy, Harper and Kunze (1979), show that even after full account is taken of the decline in capital accumulation, most of the productivity slowdown cannot be explained. The limited potency of increased investment in spurring productivity growth can be illustrated by a simple calculation.

Consider an economy which evolves according to the following model:

$$
\begin{aligned}
& \mathrm{Y}_{\mathrm{t}}=\mathrm{K}_{1}^{a} \mathrm{~L}_{\mathrm{t}}-\mathrm{a} \\
& \mathrm{K}_{\mathrm{t}}=(1-\delta) \mathrm{K}_{\mathrm{t}-1}+\mathrm{I}_{\mathrm{t}-1} \\
& \mathrm{I}_{\mathrm{t}-1}=\delta \mathrm{K}_{\mathrm{t}-1}+y \mathrm{Y}_{\mathrm{t}} \\
& \mathrm{L}_{\mathrm{t}}=(1+g) \mathrm{L}_{\mathrm{t}-1}
\end{aligned}
$$

Equation (1a) is a standard Cobb-Douglas aggregate production function. Since the variable $Y$ is to be interpreted as net output, it is plausible to take $\alpha=.15$ in using the model to interpret U.S. economic performance. ${ }^{6}$ The second equation (Ib) deseribes the

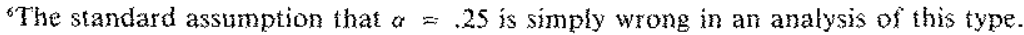
The figure of interest is the share of net retura to capital in net output. For the corporate sector, this has averaged .15 over the last quarter century.
} 
TABLE 4

The Rate of Growth of Output

Under Alternative Investment Policies

\begin{tabular}{lcccc}
\hline Years & $\gamma=.045$ & $\gamma=.060$ & $\gamma=.075$ & $\gamma=.090$ \\
\hline $0-5$ & 3.00 & 3.10 & 3.20 & 3.30 \\
$6-10$ & 3.00 & 3.11 & 3.22 & 3.31 \\
$11-20$ & 3.00 & 3.09 & 3.17 & 3.24 \\
$21-30$ & 3.00 & 3.07 & 3.13 & 3.17 \\
\hline
\end{tabular}

accumulation of capital in the standard way. In the calculations reported below, it is assumed that $\delta=, 08$. Equation (1c) specifies that net investment is a constant fraction $(\gamma)$ of net output. This figure has averaged about 4.5 percent $^{7}$ over the last two decades for the U.S. non-financial corporate sector. The final equation specifies that the effective labor force grows at rate $\mathrm{g}$. In the calculations below $\mathrm{g}$ is taken to equal .03 .

It is apparent the model has a steady state with a capital output ratio of 1.5 , and a rate of return on capital of .10 . This is quite realistic. As shown in Table 3, the pre-tax rate of return on corporate capital averaged 9.6 percent over the last decade. The 1979 capital-output ratio was 1.48 . By simulating the model it is possible to examine the effects of an increase in the share of output devoted to net investment. This is done in Table 4 which shows the rate of growth of output under alternative investment policies.

The limited potency of increasing investment to spur growth emerges clearly. Even a doubling of the share of output devoted to net investment would increase the economy's rate of growth by only 0.3 percent per year over the next decade. The long-run gains are even smaller. In steady state the rate of growth is independent of the investment rate. The effects of more feasible increases in the rate of investment are much smaller. Increasing the share of net investment by one-third would only raise the growth rate of productivity by about 0.1 percent per year over the next decade.

This calculation has assumed that all technical change is disembodied - that is, independent of the accumulation of capital. It might be argued that instead technical progress is embodied in

'This figure is greater than those in Table 1, because it takes account of growth in land and inventories. 
new capital goods, so that an increase in the rate of investment raises productivity by speeding the introduction of new technology. The model can easily be modified to take account of this possibility by allowing technical change to affect the growth of the effective capital stock rather than the effective labor force. That is, the model becomes:

$$
\begin{aligned}
& Y_{\mathrm{i}}=\operatorname{KEFF}_{\mathrm{t}} \mathbf{L}_{\mathrm{t}}^{-\alpha} \\
& \operatorname{KEFF}_{\mathrm{t}}=(\mathrm{l}+\mathrm{g})^{\mathrm{t}-1} \mathrm{I}_{\mathrm{t}-1}+ \\
& (1-d) \mathrm{KEFF}_{\mathrm{t}-1} \\
& \mathbf{K}_{\mathrm{t}}=\mathbf{I}_{\mathrm{t}-1}+(1-\delta) \mathrm{K}_{\mathrm{t}-1} \\
& \mathbf{I}_{\mathrm{t}}=\delta \mathrm{K}_{\mathrm{t}-1}+\gamma \mathbf{Y}_{\mathrm{t}-1} \\
& \mathbf{L}_{\mathrm{t}}=(\mathbf{l}+\mathbf{n}) \mathbf{L}_{\mathrm{t}-1}
\end{aligned}
$$

where $g$ is now to be taken as the rate of embodied technical change and $n$ the rate of population growth. For the U.S. economy it seems reasonable to take $\mathrm{n}=\mathrm{g}=.015$.

The results of simulating this model for alternative values of $\gamma$ are displayed in Table 5. They indicate that assuming that technical change is embodied does somewhat increase the estimated potency of increased investment. Even so, a doubling of the share of output devoted to net investment only raises the productivity growth rate by 6 percent over the first decade. This calculation surely is an overstatement since at least some technical change is disembodied.

The conclusion of this analysis, that even a large increase in the rate of investment will have only a minor effect on productivity, may at first seem surprising. However, it is in line with most previous research. One of the striking discoveries of the "growth accounting" literature dating from Solow (1958) has been the unimportance of capital accumulation as a factor accounting for increasing affluence. Estimates of the sources of inter-temporal and international differences in productivity, Denison (1979), have consistently found that capital intensity plays only a minor role. The major factors appear to be human capital and technological progress. It is little wonder, therefore, that increasing capital accumulation is not likely to have major effects on productivity growth.

Proponents of the view that increased investment would yield large output gains frequently point to the apparently high correlation across countries between capital formation and growth. It is possible that this is because high rates of capital formation spur research, or give rise to "learning by doing" effects. If so, 


\section{TABLE 5}

The Rate of Growth of Output

Under Alternative Investment Policies

with Embodied Technological Change

\begin{tabular}{lcccc}
\hline Years & $y=.045$ & $\gamma=.060$ & $y=.075$ & $y=.090$ \\
\hline $0-5$ & 3.00 & 3.21 & 3.40 & 3.59 \\
$6-10$ & 3.00 & 3.14 & 3.25 & 3.36 \\
$11-20$ & 3.00 & 3.10 & 3.16 & 3.23 \\
$21-30$ & 3.00 & 3.06 & 3.11 & 3.15 \\
\hline
\end{tabular}

conventional analyses may underestimate the gains from increased investment. However, it seems more plausible that causality runs the other way and high savings rates are caused by rapid technological progress. This implication flows naturally from the standard Life-Cycle Hypothesis. ${ }^{8}$

\section{INVESTMENT AND INFLATION}

It is difficult to know how to frame the question of the effects of policies to encourage investment on the rate of inflation. The outcome of such policies obviously depends on what other concurrent policy choices are made. We begin by considering the effects of meastres to encourage investment holding the rate of growth of money constant.

Unless there is a change in the velocity of money, the effect of increased investment on the rate of inflation is just the negative of its impact on the growth rate of real output. The calculations in the preceding section suggest that this is likely to be only a small effect on the order of several tenths of a percentage point per year.

An investment oriented tax cut is likely to raise the returns available on stocks and bonds. This will reduce the demand for money, thereby increasing velocity and tending to raise the price level. Suppose, for example, that an investment stimulus raised the yield to bond holders by one percentage point. Assuming an initial

\footnotetext{
${ }^{8}$ Two other qualifications to the analysis in this subsection shoutd be acknowledged. First, an increase in the rate of capital accumulation will tend to increase real wages, which may spur some labor supply response giving rise to extra growth. It is easy to show that this effect is likely to be negligible even if a very high labor supply elasticity is assumed. Second, the gains from additional investment may be slightly underestimated because no account is taken of the advantage from replacing energy intensive with energy conserving capital. Prefiminary analysis suggests that this effect could not possibly raise the estimates reported above by more than 1 percent.
} 
interest rate of 10 percent, and an interest elasticity of money demand of only .25 , the price level would have to rise by 2.5 percent beyond normal inflation to restore asset market equilibrium. This inflationary pressure is much greater than the deflationary force from increased productivity growth. Hence, the net effect of an investment oriented tax cut is likely to be an increase in the rate of inflation unless the rate of money growth is reduced at the same time.

Depending on the exact formulation of wage-price dynamics it is possible to argue that increases in productivity may make it possible to bring down the rate of money growth and inflation without causing unemployment. Essentially the argument is that productivity growth is like a favorable supply shock. A one-time shock, by reducing past inflation, may moderate wage demands leading to further reductions in inflation. This argument depends on the implausible premise that workers are not able to obtain higher real wages when increased capital intensity raises their productivity. It also suggests that any measure (e.g., cutting sales taxes) which reduces prices will reduce long-run inflation. Hence, it does not single out increased investment incentives as the way to fight inflation.

In sum, it does not appear that tax policies to spur investment are likely to reduce the rate of inflation. This proposition is true a fortion if account is taken of their effects on aggregate demand and the government deficit.

\section{INVESTMENT AND ENPLOYMENT}

There is no reason to favor investment oriented policies as a vehicle for encouraging employment. As long as labor and capital are substitutable, either within individual production activities or through shifts in the mix of production activities, it will be possible to achieve full employment with any level of capital intensity. Fears that insufficient capital accumulation must cause unemployment are as groundless as earlier concern about unemployment due to automation. Indeed, since capital and labor are substitutes in production, unless output also expands increased capital accumulation will actually reduce the level of employment.

\section{INVESTMENT AND INTERTEMPORAL ECONOMIC EFFICIENCY}

The justification for measures to increase the rate of economic growth, if such a justification exists, must lie in the area of intertemporal economic efficiency. There are two types of issues 
involved here which I will refer to as macro- and micro. intertemporal efficiency. Macro-efficiency here refers to society's decision about the allocation of consumption between those alive today and future generations. The huge literature on the Ramsey optimal economic growth problem is concerned with this issue. Micro-efficiency here refers to the distortion of individual consumption plans by capital income taxation. This is the subject addressed by traditional welfare analyses of the effects of capital income taxes.

\section{INVESTMENT AND MACRO-EFFICIENCY}

The allocation of consumption between current and future generations inherently involves ethical choices. Even a policy of consuming the entire capital stock and leaving nothing to future generations is Pareto optimal. Hence traditional welfare economics can offer little guidance. The problem is normally formulated on choosing a growth path to maximize the discounted value of utility subject to the constraints imposed by the production technology. That is:

$$
\begin{aligned}
& \operatorname{Max} \int_{0}^{\infty} U\left(c_{t}\right) e^{-(d+\mathrm{n}) t} d t \\
& c=f(k)-(n+g) k-\dot{k} \\
& k_{0}=\bar{k}
\end{aligned}
$$

where $\mathrm{c}$ is consumption, $\delta$ the discount rate, $\mathrm{n}$ the rate of population growth, and $g$ is the rate of Harrod-neutral technical change. It is not difficult to show (see Solow (1970) for an intuitive exposition) that an economy which is moving along a path which solves the maximization problem given in (3) approaches a steady state path with the property that:

$$
f^{\prime}(k)=\delta+\varepsilon g
$$

where $\varepsilon$ is the elasticity of the marginal utility function. A value of $\varepsilon=-1$ implies that as consumption doubles, the value of a small increase in its rate halves. With $\varepsilon=-2$, the value falls by 75 percent and so forth.

Equation (4) can be used to make a judgment about the efficiency of the path currently followed by the U.S. economy. The data in Table 1 suggest that the marginal product of corporate capital, $f^{\prime}(\mathrm{k})$, approximately equals .10. The value of $g$ is very optimistically assumed to be .02 . The parameters $\varepsilon$ and $\delta$ describing 
how the social marginal utility of consumption changes with the level of consumption and time cannot be estimated empirically. A value of $\varepsilon=-2$ implying that society is willing to take a dollar from someone with a $\$ 30,000$ income in order to transfer 12 cents to someone with an income of $\$ 10,000$ seems very egalitarian. This implies that current levels of investment are insufficient unless $\delta \geqslant .06$.

There is little that an economist can say about the value of $\delta .{ }^{9}$ However, it is difficult to see a rationale for discounting the utility of future generations at a rate nearly as high as six percent. Ramsey himself saw no argument for any discounting at all. Thus, there is an ethical argument pointing to the desirability of more capital accumulation.

It might be argued that this hardly provides a warrant for government policies to spur investment. The future will be provided for by bequests from parents to their children. The level of capital intensity ground out by the free market is almost bound to be the optimal rate. Careful consideration of this line of argument suggests that there is a presumption that private capital formation will be insufficient. First, the private return to capital is far less than the social return to investment. The data in Table 2 indicate the average return to corporate capital was about 10 percent during the 1970 s. The after-tax return to investors is only about one-fourth as great, creating a presumption that insufficient provision will be made for investment. Second, as long as individuals' concern for posterity extends to the children of others, there is a benefit externality from increased capital formation. Third, there is no more reason to rely on private provision for the future than there is to rely on private charity to meet current social needs. The existence of a transfer motive is hardly sufficient to establish the sufficiency of the resulting transfers.

While no definitive statement can be made, the foregoing arguments suggest that macro-efficiency considerations dictate the desirability of increased corporate investment. The amount of the increase is of course more difficult to judge.

\section{INVESTMENT AND MICRO-EFFICIENCY}

Even if taxation has no effect on the amount of capital accumulation, it may lead to substantial welfare costs due to the distortion of individual consumption profiles. This will be true even

\footnotetext{
Note the term $g$ in (4) already takes account of the fact that future generations will be richer than those alive today.
} 
if the overall level of capital intensity is constant at its optimal level. Feldstein (1978), Boskin (1978) and Summers (1980) all estimate annual welfare costs of capital income taxes at current levels which exceed $\$ 100$ billion annually. Below, I illustrate how capital taxes can give rise to large welfare costs, without having an effect on capital intensity.

Consider the following model. Consumers live two periods supplying labor inelastically in the first period and consuming in both periods. That is, consumers maximize:

$$
\mathrm{U}\left(\mathrm{C}_{1}, \mathrm{C}_{2}\right) \text { s.t. } \quad \mathrm{C}_{1}+\frac{\mathrm{C}_{2}}{1+(1-t) \mathrm{r}}=\mathrm{WL}
$$

where $C_{1}$ and $C_{2}$ refer to first and second period consumption, $t$ is the tax rate on capital income, and $W \bar{L}$ is first period income. If the utility function is Cobb-Douglas, $U=\mathrm{C}_{9} \mathrm{C}_{2}^{-\alpha}$, it is easy to show that $C_{3}=\alpha W L$ independent of the capital income tax rate. Thus the tax has no effect on the level of capital formation which is given by:

$$
K=W \widetilde{L}-C_{t}
$$

The welfare cost of the tax can easily be measured. Solving the maximization problem (5) it can be shown that the indirect function is given by:

$$
\mathrm{V}(t, r, \mathrm{WL})=\mathrm{W} \widetilde{\mathrm{L}} \alpha^{\alpha}(1-\alpha)^{\alpha}(1+(1-t) r)^{(1-\alpha)}
$$

This expression can be solved to find the change in labor income necessary to compensate the representative consumer for any given change in his tax rate on capital income. The revenue yield of the tax can then be subtracted from this expression to calculate the deadweight loss.

This model is highly stylized. Nonetheless, it can provide some insight into the orders of magnitude of the welfare losses from capital income taxation. It is assumed that each period in the model corresponds to a generation, or 25 years. Hence, the value of $\alpha$ is taken to equal .5 , and the pre-tax rate of return is taken to be $\mathrm{e}^{.0\{25)}=12.18$.

These parameters imply that relative to lump sum taxation, the welfare loss from a 75 percent tax rate on capital income is 8 percent of labor income, compared to 4 percent of labor income for a 50 percent capital tax rate, and 1 percent with a 25 percent tax rate. These welfare losses are very large--a 50 percent capital income tax has a welfare loss of over $\$ 50$ billion annually at current 
levels of national income. As is to be expected, the welfare loss rises much more than proportionally with the tax rate. Cutting the tax rate by one-third from 75 percent to 50 percent reduces the deadweight loss by one-half. A further halving of the tax rate to 20 percent reduces the loss by three-quarters. Thus the marginal gains in intertemporal efficiency from cutting high capital tax rates are large. The reduction in deadweight loss equals half the revenue loss in the case of reduction in the tax rate from 75 to 50 percent.

This calculation omits two important features of reality. The result may be overstated because of the assumption that lump sum taxes are available. If the atternative is the taxation of labor income, then deadweight losses may also result from this source. However, it is not at all clear that consideration of variable labor supply would reduce rather than increase the estimated welfare losses from capital taxation. Capital taxes, by raising the price of future consumption, reduce real wages as defined by an appropriate intertemporal cost of living index. ${ }^{10}$ Hence, they also distort the labor-leisure choice. Moreover, they distort the intertemporal allocation of labor, which is not affected by a labor income tax. ${ }^{31}$ Feldstein (1978), without considering the latter effect, found that there are substantial net gains which can be realized from a shift towards labor taxes. Considering the intertemporal labor supply effects would strengthen this conclusion.

The calculation also is carried on as if all capital were located in the corporate sector. This means the final losses from the misallocation of capital are not included. Avarlable evidence, Fullerton, et al. (1976), suggests that these losses may not be too great.

Any reduction in the tax burden on corporate capital would tend to reduce the wedge between the social return to capital and investors" private return, and so would reduce the deadweight loss. The calculation presented here suggests that even if the policy did not increase capital formation there would be substantial gains in intertemporal economic efficiency. If parameter values consistent

${ }^{1}$ This crucial point is overlooked by many authors who hold that with variable labor supply, optimal tax rules are completely indeteminable. In the plausible case of separable utitity, it is optimal to place no taxes on labor income regardiess of the elasticity of labor supply. It is easy to construct examples in which a subsidy to capital income is optimal.

"A long tradition in labor econonics dating from the work of Mincer has recognized that the intertemporal elasticity of labor supply far exceefs the static elasticity. 
with a positive effect of investment incentives on saving had been assumed the estimated welfare gains would have been much greater.

These results imply that there is a substantial scope for improving economic welfare through increased incentives for investment. The next sections discuss the empirical estimation of the extent to which tax policy can increase investment.

\section{Traditional Approaches to Evaluating Corporate INVESTMENT INCENTIVES}

This section examines previous empirical evidence on the relationship between corporate investment and tax policy. The large literature on this subject is based almost entirely on single equation econometric models of the demand for equipment and structures. A detailed survey and criticism of some prominent models may be found in Chirinko and Eisner (1980). There have been relatively few efforts to examine the effects of investment stimuli within plausible general equilibrium frameworks. The efforts of this type which have taken place have been carried out using large scale econometric models which are ill-suited to questions of long-run capacity growth.

The standard method of evaluating the effects of tax policy on investment follows the seminal work of Hall and Jorgenson (1967). They begin by postulating that the desired capital stock, $\mathrm{K}^{*}$, depends on the level of output, $Y$, and the cost of capital, $c$. The cost of capital is a complex function of the interest rate and tax parameters. A general expression for it is given by

$$
c=\frac{q\left[(1-u) e-\frac{q}{q}+d\right][1-k-u z]}{(1-u)}
$$

where $\mathrm{q}$ is the supply price of capital goods, $\mathrm{u}$ is the corporate income tax rate, $\varrho$ is the opportunity cost of capital, $\delta$ is the rate of economic depreciation, $k$ is the investment tax credit, and $z$ is the present value of the tax depreciation expected from a dollar of investment.

From this point, empirical implementations differ across studies. It is usually assumed that the rate of investment depends on some distributed lag on K.* The distributed lag is usually justified as deriving from lags in the delivery of investment goods or in the formation of expectations. The equation is then estimated econometrically. 
Changes in tax policy are studied by examining the effects of a tax change on the cost of capital and then of the cost of capital on investment. Chirinko and Eisner (1980) present a detailed description of how this is done in the major large scale econometric models.

While there is room for substantial disagreement about the proper way to carry out this procedure, these issues are ignored here. There are several fundamental problems which make this approach an undesirable way of evaluating investment incentives.

First, by holding the level of output fixed, the investment equation approach makes it impossible to capture the effects which are at the root of the case for tax policies to encourage investment. If one believed that the level of output was in fact independent of the path of investment, it is difficult to see why investment stimuli should be advocated. The essence of the way in which investment stimuli are supposed to work is by reducing the cost of capital and encouraging firms to increase investment in order to supply more output.

The second fundamental difficulty with these investment functions is that they are susceptible to the "Lucas critique." There is no reason to suppose that their parameters would remain constant if policy rules were changed. Hence they cannot provide useful policy guidance. A trivial example is provided by considering the difference between a variable and a permanent tax credit. It is easy to see that a temporary credit will provoke a much greater investment response since firms will all schedule their investment to coincide with it. Hence the estimated effect of the investment tax credit (ITC) will depend on what policy rule has been followed. A related point is that conventional investment equations offer no way of considering the effects of policy announcements. Taken literally, the investment equations in all the major macro-econometric models would imply that an announcement today that six months hence the corporate income tax would be abolished would have no effect at all on current investment decisions. Nor does anything in the equations suggest how they might be modified to meet this objection.

The third difficulty with traditional investment equations is that they are really adjustment equations without a theory of adjustment. The question of ultimate interest is the effect of changes in tax policy on the long run capital stock. This question can be answered simply from the production function requirement, $F_{K}=c$, holding that the marginal product of capital is equated to its 
rental cost. The investment equation is essentially irrelevant. Seen in this light, it is clear that the focus of efforts to examine the effects of tax policy should be on the aggregate production function rather than the investment equation. Worse, the production functions which are implied by the results of fitting investment equations are typically wildly implausible.

The only role for an investment equation is in explaining the economy's adjustment path in response to a policy shock. Yet existing econometric investment equations proxy adjustment without any explicit treatment of adjustment costs. They can hardly be interpreted as offering useful guidance on the process of convergence to equilibrium because the equilibria they imply are typically so far wide of the mark.

\section{THE ROLE OF DEMAND}

Previous studies all suggest that the state of business activity is a prime determinant of the level of investment. It is this evidence that has led many observers to conclude that more vigorous antirecession policies offer the greatest hope for raising the level of investment. This conclusion typically emerges from both single equation studies (e.g., Clark (1979)) and full model simulations. This finding can be traced directly to the flaws in these studies noted above. In fact, economic theories which command almost universal support among Keynesians as well as classical macroeconomists indicate that reliance on the accelerator offers no route to increased capital formation in the long run.

The high correlation between output and investment which is observed in the data does not imply that a permanent increase in the level of output will permanently increase the rate of investment. As emphasized above, output and investment are simultaneously determined and in the past have moved in tandem because of common causes. Indeed the apparent potency of the accelerator reflects, in large part, the impact of investment on total output. It does not follow that the correlation would be the same if general expansionary policy was regularly used to spur investment.

There is a second important argument supporting this conclusion. Many, though not all, previous investment studies fail to impose the restriction that investment depends only on the growth in output not its level. Since high output has in the past been correlated with high output growth it appears that expansion is a potent policy to stimulate investment. A policy of permanent expansion would eliminate this correlation and so would be much 
less effective than conventional econometric specifications suggest.

The analysis so far has been partial equilibrium in character. It has suggested that there is reason to doubt that a permanent increase in GNP would have a large impact on investment. There is, however, a much more fundamental flaw in the argument for expansionary policy to spur investment. Stated baldly, the natural rate hypothesis implies that there is no such thing as "permanent expansionary policy." Any attempt to keep the level of economic output performance above some "natural" level, will lead to accelerating inflation. If we rule out policy rules which will lead to steadily increasing rates of inflation, we are confined to policies which on average keep the economy at its natural rate. Permanent expansion or contraction is not possible.

What about a policy of systematically more vigorous response to recessions than has been observed in the past? While this would increase investment, it would also lead to permanently accelerating inflation, unless an equal of fset was applied in boom times. Such an offset would negate any gains which might be realized in terms of investment.

\section{EvaluATING INVESTMENT INCENTIVES}

This section summarizes the methodology for evaluating investment incentives developed in Summers (1980), and presents some estimates of the effects of alternative tax policies on investment. The method described here is an application of Tobin's $q$ theory of investment. It yields estimates of the effects of tax policies on the valuation of the stock market as well as on rate of investment. Below I present a heuristic account of the method. For a fuller treatment, the reader is referred to my earlier paper.

\section{METHODOLOGY}

For simplicity, the dynamics of investment and market valuation are examined in a simplified model where all investment is financed through retained earnings and the only tax is a proportional levy on corporate income. In this setting it is reasonable to assume that investment depends on the ratio of the market value of existing capital to its replacement cost. Unless the market value of the firm will be increased by more than one dollar by a one dollar investment, there is no reason for it to be undertaken. Given costs of adjustments and lags in recognition and implementation, there is no reason to expect that all investments which will raise market value by more than their cost will be made immediately. As Tobin 
(1969) has argued, these considerations lead to an investment equation of the form: ${ }^{12}$

$$
\begin{gathered}
I=I\left(\frac{V}{K}\right) K \\
I(1)=0 \quad I^{\prime}>0
\end{gathered}
$$

where $I$ represents gross investment and $V / K$ is the " $q$ " ratio of market value to replacement cost. The assumption that it is $I / K$ which depends on $q$ insures that the growth rate of the capital stock does not depend upon the scale of the economy.

It is assumed that equity owners require a fixed real rate of return to induce them to hold the existing stock of equity. This return comes in the form of dividends, equal to after-tax profits less retentions for new investment, and capital gains. Hence we have the condition:

$$
e=\frac{\text { Div }}{V}+\frac{\dot{V}}{V}
$$

which implies:

$$
\dot{\mathrm{V}}=\varrho \mathrm{V}-(\mathrm{l}-\tau) \mathrm{F}^{\prime}(\mathrm{K}) \mathrm{K}+\mathrm{I}\left(\frac{\mathrm{V}}{\mathrm{K}}\right) \mathrm{K}-\delta \mathrm{K}
$$

where $r$ is the corporate tax rate, and $F(K)$ is the production function for net output.

It will be most convenient to examine the dynamics in terms of $\mathrm{K}$ and $\mathrm{q} \equiv \frac{\mathrm{V}}{\mathrm{K}}$. Equations (9) and (11) imply that the system's equations of motion are:

$$
\begin{gathered}
\dot{K}=I(q) K-\delta K \\
\dot{q}=\rho q-I(q) q+d q+I(q)-(l-\tau) F^{\prime}(K)-\delta
\end{gathered}
$$

where $d$ is the rate of depreciation.

The steady state properties of the model are easily found by imposing the conditions $\dot{\mathrm{K}}=0$ and $\dot{\mathrm{q}}=0$. These imply:

$$
\begin{gathered}
q=I^{-1}(\delta) \\
(l-\tau) F^{\prime}(K)=\varrho q
\end{gathered}
$$

${ }^{12}$ A rigorous foundation for an investment equation of this type is provided tn Abel (1979) and Hayashi (1980). An important implicit assumption of this approach is the homogeneity of capilal. If capital is heterogeneous, shocks may reduce the market value of existing capital but raise the return on new investment. The recent energy shock illustrates this phenomenon. 
The former equation indicates that the steady state value of $q$ must be greater than 1 by an amount just large enough to induce sufficient investment to cover depreciation. The latter equation holds that firms equate their net marginal product of capital to the cost of capital. Inspection of (14) and (15) makes it clear that a change in the corporate tax rate affects the steady state capital stock but has no effect on steady state $\mathrm{q}$. This is a consequence of the assumption that it is investment relative to the capital stock which varies with $q$.

The phase diagram of the system (12) and (13) is displayed in Figure 1. It is readily verified that the pair of equations is saddle point stable ${ }^{13}$. The arrows indicate the direction of motion and the heavy line represents the saddle point path along which the system will converge. A change in the corporate tax rate is depicted in Figure $2^{14}$. If the expectations about pre-tax profits were static, the value of $q$ would jump from $E$ to $A$ when the tax change took place. This expectations assumption has been used in previous works on the effects of taxation on the stock market, e.g., Feldstein (1979), Hendershott (1979). It neglects the effect of the induced changes in investment on the present value of future profits. With perfect foresight, as assumed here, the value of $\mathrm{q}$ will jump only to $B$. The magnitude of the jump will depend upon the speed of adjustment of the capital stock to the shock.

The system of equations (12) and (13) can be solved numerically to estimate the impact of any type of shock on the path of $q$ and the capital stock. The effect of tax changes on the level of the stock market can be easily calculated. This can then provide a basis for estimating the effects of tax changes. The model actually used to calculate the effects of tax changes is considerably more complex. It takes account of the complexities of the tax code and of the fact that investment is partially financed through the issuance of debt. The results reported below are based on empirically estimated production functions and investment relations for the corporate sector.

\section{RESULTS}

We begin by considering the impact of the investment tax credit, since this issue has been a focus of previous work. Standard single equation approaches to the investment function have yielded

\footnotetext{
"This is a common feature of models with asset prices.

${ }^{14}$ It is assumed that the market selects the घnique stable perfect foresight path.
} 


\section{TABLE 6}

Permanent and Temporary Removal of the Investment Tax Credita

\begin{tabular}{|c|c|c|c|c|c|c|}
\hline \multirow[b]{2}{*}{ Yeat } & \multicolumn{3}{|c|}{ Permanent } & \multicolumn{3}{|c|}{ Temporary } \\
\hline & $\mathrm{V}$ & 1 & $\mathrm{~K}$ & $\mathrm{~V}$ & 1 & $\mathrm{~K}$ \\
\hline 1 & $-2.8 \%$ & $-6.0 \%$ & $0 \%$ & $-2.0 \%$ & $0 \%$ & $0 \%$ \\
\hline 2 & $-3.0 \%$ & $-4.8 \%$ & $-0.4 \%$ & $-0.5 \%$ & $0_{0}^{0}$ & $-0.1 \%$ \\
\hline 3 & $-3.0 \%$ & $-4.9 \%$ & $-0.9 \%$ & $-0.5 \%$ & $0 \%$ & $-0.1 \%$ \\
\hline 4 & $-3.3 \%$ & $-6.1 \%$ & $-1.3 \%$ & $-0.6 \%$ & $-4.9 \%$ & $-0.1 \%$ \\
\hline 5 & $-3.5 \%$ & $-6.2 \%$ & $-1.7 \%$ & $-0.6 \%$ & $-3.7 \%$ & $-0.4 \%$ \\
\hline 10 & $-4.0 \%$ & $-6.4 \%$ & $-3.5 \%$ & $-0.3 \%$ & $0 \%$ & $-0.9 \%$ \\
\hline 15 & $-4.4 \%$ & $-7.9 \%$ & $-4.8 \%$ & $-0.3 \%$ & $0 \%$ & $-0.7 \%$ \\
\hline 20 & $-4.7 \%$ & $-8.1 \%$ & $-6.0 \%$ & $0 \%$ & $0 \%$ & $-0.6 \%$ \\
\hline 50 & $-5.6 \%$ & $-8.8 \%$ & $-8.9 \%$ & $0 \%$ & $0 \%$ & $-0.1 \%$ \\
\hline $\begin{array}{l}\text { Steady } \\
\text { State }\end{array}$ & $-5.6 \%$ & $-9.6 \%$ & $-9.6 \%$ & $0 \%$ & $0 \% 0$ & $0 \%$ \\
\hline
\end{tabular}

Notes. aThe numbers shown in the table are the changes relative to the 8 percent inflation path in the atsence of tax reform.

the temporary investment tax credit is inposed in year 4 for three years.

divergent results. In perhaps the most widely cited study, Hall and Jorgenson (1971) conclude that the investment tax credit has a potent impact, which reaches its peak after about three years. They estimated that the 7 percent credit on equipment enacted in 1962 raised the 1970 capital stock by about 4 percent above the level it would have reached in the absence of the credit. Other estimates typically suggest much smaller estimates of the effect of the credit. None of the estimates takes explicit account of the possibly temporary nature of changes in the level of the credit.

In Table 6 the effects of alternative tax credit policies are considered. The first column considers the effects of a correctly perceived permanent removal of the credit. The results indicate that the credit has potent effects on investment, even though it has only a small impact on market valuation in the short run. Its immediate effect is to reduce investment by about 6 percent, and it decreases the capital stock by 8.9 percent in the long run. The estimated response is much more gradual than that predicted by standard 
investment equations. The effect on investment declines between the first and second years and then rises steadily as the reduced capital stock requires less replacement investment. Since the change considered here is the removal of a 9 percent investment credit, these results indicate a slightly larger effect than those of Hall and Jorgenson, and a much larger effect than that found in most other studies.

The right half of the table considers the impact of a temporary removal of the ITC. Such a measure leads to a sharp decrease in investment during the suspension period. This leads to an increase in net investment after the suspension is removed. Gross investment does not increase because the lower capital stock requires less replacement investment. Note that the catch-up following the restoration of the credit is very slow. Two-thirds of the gap caused by the suspension in the capital stock remains 15 years later. These results show the importance of the adjustment costs, which explain investment's sluggish response to $q$. In the absence of any adjustment costs, one would expect to see substantial disinvestment during the period of the suspension. Because the adjustment costs of returning to the steady state capital stock would be high, this does not take place. These findings illustrate the importance of considering expected future policy. If the credit suspension were permanent its effects on net investment in the short run would be far less pronounced.

The effects of reductions in the corporate tax rate are examined in Table 7. An immediate rate reduction from .48 to .40 is constrasted with an announcement that in year 4 , such a tax cut will take place. Both measures are equivalent in the long run, and raise the steady state capital stock by 15.7 percent. They increase the long-run value of the stock market significantly more because the reduced corporate tax raises the effective price of new capital goods by diminishing the value of accelerated depreciation and the expanding of adjustment costs.

The simulations show that the announcement policy has a significantly greater short-run impact on investment than the immediate implementation policy. The former raises the capital stock by 3 percent after three years compared with 2 percent for the latter. This occurs even though the immediate implementation policy has a greater immediate impact on the capital stock. The reason again is the effects of accelerated depreciation and the expanding of adjustment costs. Firms find it optimal to accelerate their investment plans to take account of the lower effective price 


\section{TABLE 7}

Unanticipated and Anticipated Permanent

Corporate Tax Cut ${ }^{\mathrm{a}}$

\begin{tabular}{|c|c|c|c|c|c|c|}
\hline \multirow[b]{2}{*}{ Year } & \multicolumn{3}{|c|}{ Unanticipated } & \multicolumn{3}{|c|}{${ }^{\mathrm{b}}$ Anticipated } \\
\hline & $\mathrm{V}$ & I & $\mathrm{K}$ & $\mathrm{V}$ & I & $\mathbf{K}$ \\
\hline 1 & $+18.6 \%$ & $+7.10 \%$ & $0 \%$ & $+15.10 \%$ & $+9.50 \%$ & $0 \%$ \\
\hline 2 & $+19.4 \%$ & $+7.2 \%$ & $+0.5 \%$ & $+16.9 \%$ & $+10.8 \%$ & $+0.8 \%$ \\
\hline 3 & $+20.0 \%$ & $+8.5 \%$ & $+1.1 \%$ & $+19.0 \%$ & $+12.2 \%$ & $+1.6 \%$ \\
\hline 4 & $+20.40 \%$ & $+7.3 \%$ & $+1.6 \%$ & +20.9070 & $+8.5 \%$ & $+2.5 \%$ \\
\hline 5 & $+20.7 \%$ & $+8.6 \%$ & $+2.0 \%$ & $+21.2 \%$ & $+8.6 \%$ & $+3.0 \%$ \\
\hline 10 & $+22.3 \%$ & $+9.0 \%$ & $+4.5 \%$ & $+22.7 \%$ & $+10.3 \%$ & $+5.1 \%$ \\
\hline 15 & $+23.2 \%_{0}$ & $+10.5 \%$ & $+6.5 \%$ & $+23.5 \%$ & $+10.5 \%$ & $+7.0 \%$ \\
\hline 20 & $+24.1 \%$ & $+10.8 \%$ & $+8.1 \%$ & $+24.3 \%$ & $+10.8 \%$ & $+8.6 \%$ \\
\hline 50 & $+25.9 \%$ & $+14.70 \%$ & $+13.5 \%$ & $+25.90 \%$ & $+14.7 \%$ & $+13.8 \%$ \\
\hline $\begin{array}{l}\text { Steady } \\
\text { State }\end{array}$ & $+26.7 \%$ & $+15.3 \%$ & $+15.3 \%$ & $+26.9 \%$ & $+15.3 \%$ & $+15.3 \%$ \\
\hline
\end{tabular}

Notes: aSee footnote (a) in Table 6

bTax cut takes place in year 4

of capital goods which prevails before the tax reduction actually takes place. This implies that if the goal of the corporate rate reduction is to increase capital formation, the measure should be announced well in advance of its enactment. Similar considerations suggest that a temporary increase in the corporate tax rate would actually spur investment.

These findings have important policy implications. They indicate that a policy of announcing a future reduction in corporate taxes will spur investment with no current revenue loss. Indeed, the effect on investment would actually be enhanced if corporate taxes were raised immediately and then cut. By combining temporary corporate rate increases with temporary increases in the investment tax credit or accelerated depreciation it would be possible to provide substantial investment stimulus at no budgetary cost.

Most previous analyses of the effects of investment incentives have neglected the role of individual tax measures. The effects of reforms in the individual tax system are considered in Table 8. Eliminating capital gains taxes would raise the stock market by 7.3 


\section{TABLE 8}

Reforms in Individual Taxes ${ }^{a}$

\begin{tabular}{|c|c|c|c|c|c|c|}
\hline \multirow[b]{2}{*}{ Year } & \multicolumn{3}{|c|}{$\begin{array}{l}\text { Capital Gains } \\
\text { Tax Eliminated }\end{array}$} & \multicolumn{3}{|c|}{$\begin{array}{c}\text { bAnticipated } \\
\text { Dividend Relief }\end{array}$} \\
\hline & V & I & K & V & I & $\mathrm{K}$ \\
\hline 1 & $+7.3 \%$ & $+11.9 \%$ & $0^{0 \%}$ & $+60.3 \%_{0}$ & $+40.5 \%$ & $0 \%$ \\
\hline 2 & $+8.1 \%$ & $+12.0 \%$ & $+0.9 \%$ & $+68.5 \%$ & $+47.0 \%$ & $+3.2 \%$ \\
\hline 3 & $+8.5 \%$ & $+13.4 \%$ & $+1.8 \%$ & $+77.3 \%$ & $+53.7 \%$ & $+6.7 \%$ \\
\hline 4 & $+8.9 \%$ & $+12.2 \%_{0}$ & $+2.7 \%$ & $+86.3 \%$ & $+6.1 \%$ & $+10.7 \%$ \\
\hline 5 & $+9.3 \%$ & $+13.6 \%$ & $+3.60 \%$ & $+85.7 \%$ & $+6.20 \%$ & $+10.2 \%$ \\
\hline 10 & $+10.8 \%$ & $+16.7 \%$ & $+7.5 \%$ & $+83.7 \%$ & $+5.1 \%$ & $+8.5 \%$ \\
\hline 15 & $+12.1 \%$ & $+17.1 \%$ & $+11.1 \%$ & $+82.5 \%$ & $+4.0 \%$ & $+7.0 \%$ \\
\hline 20 & $+13.2 \%$ & $+20.30 \%$ & $+14.0 \%$ & $+82.0 \%_{0}$ & $+2.7 \%_{0}$ & $+5.7 \%$ \\
\hline 50 & $+16.1 \%$ & $+26.5 \%$ & $+24.0 \%$ & $+79.3 \%$ & $+1.5 \%$ & $+1.7 \%$ \\
\hline $\begin{array}{l}\text { Steady } \\
\text { State }\end{array}$ & $+17.3 \%$ & $+27.7 \%$ & $+27.7 \%$ & $+78.6 \%$ & $0 \%$ & $0 \%$ \\
\hline
\end{tabular}

Notes: aSee footnote (a) in Table 6

${ }^{b}$ Expected abolition of the dividend tax in year 4

percent in the short run. Because it would increase the advantages to the firm of retaining earnings, the impact on investment is substantially greater. Its long-run effect would be to raise the capital stock by 29.5 percent. The transition is however very gradual with only half the adjustment occurring within the first decade.

The second reform considered is an announcement that in year 4, the dividend tax will be eliminated. This corresponds to an extreme form of partial integration of the corporate income tax. As explained in Summers (1980), changes in the dividend tax rate have no effect on steady state capital intensity. The announcement that a dividend tax reduction will occur however gives firms a very large incentive to defer paying of dividends. This is done by accelerating investment. The simulations suggest that the announcement effect raises investment by 40.5 percent.

The estimates of the potential gains from reductions in taxes on capital income described here are quite robust. As explained in the previous section, the long-run results depend almost entirely on the production function. The Cobb-Douglas form which provides the 
basis for the estimates reported here is widely accepted as a reasonable aggregate approximation. The propositions that the stock market's level reflects the present value of future profits, or that investment responds positively to $\mathrm{q}$ are also uncontroversial. This is all that is necessary to accept these results.

Taken together the results indicate the large scope for tax policy to affect capital accumulation in the long run. Politically conceivable measures, such as the abolition of capital gains taxes or the allowing of replacement cost depreciation would have a very substantial impact on long-run capital intensity. Measures can be designed which have a large impact on investment with a relatively low cost in foregone government revenue. A final conclusion which emerges from these simulations is the dangers of indiscriminate tax cutting. The incentive effects of announced and unannounced cuts vary greatly across tax measures so that careful policy design can increase the investment stimulus per dollar of lost government revenue.

\section{THE SUPPLY OF FUNDS FOR CORPORATE INVESTMENT}

The analysis in this paper so far has assumed that the rate of return required by investors in the corporate sector is fixed, independent of tax policy or the level of corporate investment. As Figure 2 illustrates, this is equivalent to assuming that the supply of funds to the corporate sector is perfectly elastic. Unless this condition is met, investment incentives will lead to increases in the rate of return required by corporate investors. In the limiting case where the supply of funds to the corporate sector is completely inelastic, and the KS curve in Figure 1 is vertical, investment stimuli will have no effect on capital accumulation.

It is therefore crucial to assess the elasticity of the supply of capital to the corporate sector. A full discussion of this issue is outside the scope of this paper, but a few remarks are sufficient to establish that the elasticity is likely to be quite high. The elasticity of the supply of savings to the corporate sector depends on both the elasticity of total savings with respect to the rate of retum and the substitutability of corporate and non-corporate assets in wealth portfolios. These issues are considered in turn.

Until recently, it was widely believed that the rate of saving was largely independent of the rate of teturn. This notion was supported by verbal reference to conflicting income and substitution effects, and to the near constancy of the saving rate. Recently, both 
FIGURE 1

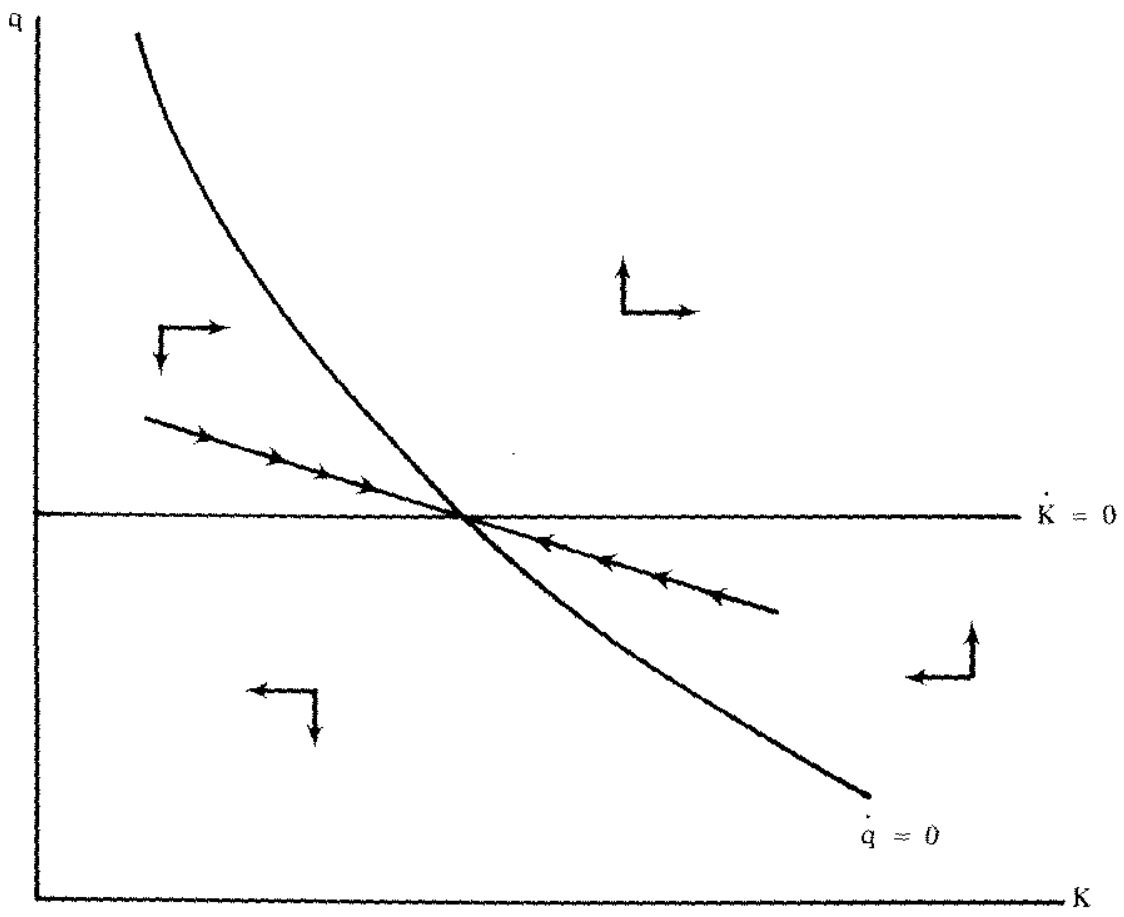

theoretical and empirical evidence have accumulated suggesting that the elasticity is quite high. The "infinite horizon" model of intertemporal consumption decisions implies that saving is perfectly elastic with respect to the interest rate. Summers (1980) shows that plausible life cycle formulations almost inevirably imply a high interest elasticity of saving. It also demonstrates that the two period model which provided the basis for most previous theoretical studies of the interest elasticity of saving is likely to be very misleading.

At the same time, recent empirical evidence tends to support a positive interest elasticity of saving. Boskin (1978) was the first study to use a measure of the proper variable, the real after-tax interest rate, in a study of the interest elasticity of saving. His study found an interest elasticity of about .4. There are strong reasons to believe that this is an underestimate of the elasticity of response to a permanent change in tax policy. The variations in teal after-tax interest rates during Boskin's sample period are almost all transitory. As Summers (1980) shows, the response of policy to a 
FIGURE 2

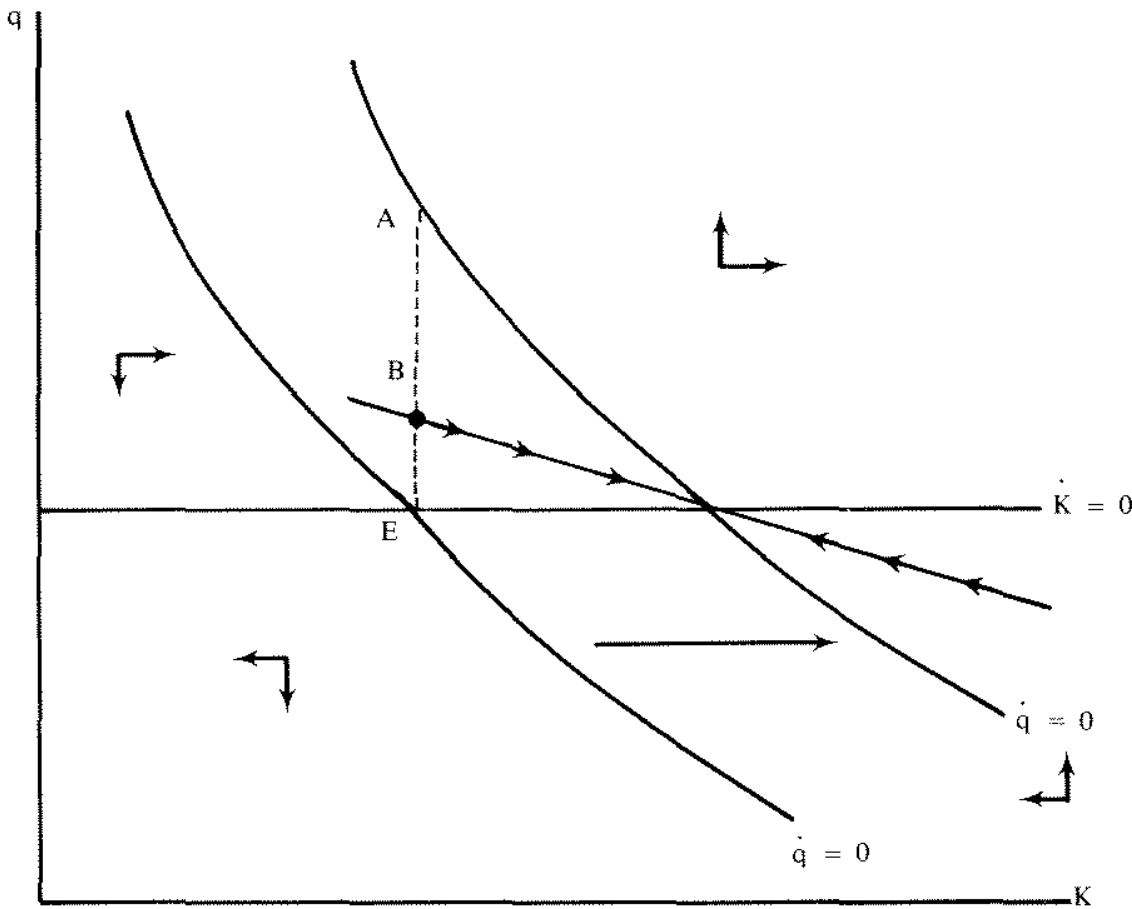

transitory shock in interest rates is likely to be much less than the response to a permanent shock. Of greater importance, Boskin, in calculating the interest elasticity of saving, takes no account of the wealth effects of interest rate changes. Part of the saving response to increases in interest rates occurs because of induced changes in wealth. Taking account of these effects can easily raise the estimated elasticity from .4 to 2 .

These considerations suggest that there are strong reasons to believe that the supply of capital to the corporate sector is highly elastic. This conclusion is strengthened by considering the allocation of capital between sectors. The U.S. corporate sector accounts for only about one-fifth of American physical wealth and a much smaller fraction of world capital. Hence even if the total supply of capital were fixed, the supply of capital to the corporate sector might be quite elastic. There is no direct evidence bearing on the extent of these effects. Summers (1981) shows how the relative valuation and accumulation of corporate and housing capital over the last decade has been affected by increased taxation. 
In Feldstein and Summers (1978) an attempt is made to gauge the elasticity of the supply of capital to the corporate sector. This is done by examining the effects of changes in the MPIR - the Maximum Potential Interest Rates firms can afford to pay on a given investment project - on actual interest rates. The results indicate that a one percentage point increase in the MPIR raises interest rates by .25 points. Loosely speaking, this means that 25 percent of the stimulus afforded by investment tax incentives is offset by rising asset prices. This is further evidence that investment incentives are unlikely to be crowded out by rising costs of capital.

If crowding out due to a limited supply of capital appeared to be a significant factor impeding corporate investment, government policy could easily increase the supply of funds to the corporate sector. This could be done through measures to encourage saving or more plausibly through increased public saving. The latter action could be achieved by reducing budget deficits and limiting commitments to future expenditures.

The analysis here of the supply of funds to the corporate sector has important implications for policy towards investment. In particular it implies that measures directed at increasing national saving will have little effect on investment. In the limiting case where saving is infinitely elastic, such measures would have no effect at all. Policies to spur investment, if they are to be effective, must be specifically directed at corporate capital. Our analysis suggests that such measures are likely to have potent effects. 


\section{REFERENCES}

Abel, Andrew. "Investment Theory: An Integrative Approach." mimeo, 1979.

Blinder, Alan. Discussion of Martin Feldstein. "Tax Rules and the Mismanagement of Monetary Policy." American Economic Review, 70 (May 1980), 189-190.

Boskin, Michael. "Taxation, Saving and the Rate of Interest." Journal of Political Economy, (April, 1978).

Chirinko, Robert and Robert Eisner. "The Effects of Tax Policies on Investment in Large Scale Econometric Models." Paper presented at the 4th World Congress of The Econometric Society, August 28, 1980.

Denison, Edward. Accounting for Slower Economic Growth: The United States in the 1970s. Brookings Institution, 1979.

Feldstein, Martin. "Investment, Inflation, and Taxes." mimeo, 1980.

and James Poterba. "State and Local Taxes and the Rate of Return on Nonfinancial Corporate Capital." NBER Working Paper \#508R, July 1980.

and Lawrence H. Summers. "Inflation, Tax Rules, and the Long Term Interest Rate." Brookings Papers on Economic Activity, 1978:1.

\section{"Inflation and the Taxation of Capital}

Income in the Corporate Sector." National Tax Journal, 32 (December 1979), 445-470.

Fullerton, Don, et al. "Static and Dynamic Resource Allocation Effects of Corporate and Personal Tax Integration in the U.S.: A General Equilibrium Approach." NBER Working Paper \$337, April 1979.

Hall, Robert and Dale Jorgenson. "Tax Policy and Investment Behavior." American Economic Review, 57 (June 1967), $391-414$

Hayashi, Fumio. "The q Theory of Investment: A Neo-Classical Interpretation." Econometrica. 
Norsworthy, J.R., Michael Harper, and Kent Kunze. "The Slowdown in Productivity Growth: Analysis of Some Contributing Factors." Brookings Papers on Economic Activity, $1979: 2,387-421$.

Solow, R.M. Growth Theory, Oxford University Press, 1970.

Summers, Lawrence H. "Taxation and Capital Accumulation in a Life Cycle Growth Model." American Economic Review, forthcoming. (1981).

"Inflation, Taxation and Corporate Investment." mimeo, 1980.

Tobin, James. "A General Equilibrium Approach to Monetary

Theory." Journal of Money Credit and Banking, 1 (1969), 15-29. 